\title{
Progesterone Receptor Status May be the Most Important Prognostic Factor for Meningiomas
}

\author{
Abdurrahman CETIN ${ }^{1}$, Sahin LACIN ${ }^{2}$, Nilgun SOGUTCU ${ }^{3}$ \\ ${ }^{1}$ University of Health Sciences, Diyarbakır Gazi Yasargil Training and Research Hospital, Department of Nuorosurgery \\ ${ }^{2}$ University of Health Sciences, Diyarbakır Gazi Yasargil Training and Research Hospital, \\ Department of Medical Oncololgy \\ ${ }^{3}$ University of Health Sciences, Diyarbakır Gazi Yasargil Training and Research Hospital, Department of Pathology, \\ Diyarbakır, TURKEY
}

\begin{abstract}
The aim of this study examined the relationships between progesterone receptor (PR) and estrogen receptor (ER) status in meningiomas and tumor grade, proliferative index (Ki67), and prognosis. Immunohistochemistry with monoclonal rabbit antibodies was performed on $4 \mathrm{~mm}$ paraffin sections of all tumors that were confirmed as meningiomas. Samples were assessed for tumor grade, PR and ER expression, and Ki67 status. Correlations among these parameters and their prognostic values were investigated. Overall survival (OS) was 91.4 months, and there was a significant difference in OS between genders. OS for females and males was 100.2 and 45.7 months, respectively $(p=0.02)$. When patients were divided into two groups by age, there was a significant difference in OS between those aged 50 years and younger and those older than 50 years, 113.2 and 65.1 months, respectively $(p=0.001)$. There was also a significant difference in OS based on PR status. OS among PR-negative patients was 43.8 months, whereas it was 93.7 months in weakly positive patients, and 95.2 months in strongly positive patients ( $p=0.035)$. Overall, 10 (13.5\%) patients had ER expression detectable by the monoclonal antibody technique used. All ER-positive tumor samples were from female patients; all tumors from males were negative for ER staining. Female predominance of meningiomas as the most common primary intracranial neoplasm strongly suggests that sex hormones may affect meningioma growth. This study found that PR status was a prognostic factor in our meningioma series, as were gender and age.
\end{abstract}

Keywords: Meningioma, Estrogen receptor, Progesterone receptor, Grade, Neoplasm

\section{ÖZET}

\section{Progesteron Reseptör Durumu Meningiomlar İçin En Önemli Prognostik Faktör Olabilir}

Bu çalışmamızda amaç progesteron ve östrojen reseptör durumunun meningiomalardaki önemi ve tümör gradi, çoğalma hızı ve prognoz ile ilişkisinin değerlendirilmesidir. Meningioma tanısı kesinleşmiş hastaların $4 \mathrm{~mm}$ parafin kesitleri monoklonal tavşan antikorları ile değerlendirildi. Hastaların patolojik örnekleri tümör gradi, PR ve ER ekspresyonları ve Ki67 durumları açısından değerlendirildi. Bu parametrelerin prognostic değerleri ve aralarındaki korelasyonlar araștııılı. Tüm hastaların genel sağkalımı (OS) 91.4 ay ve cinsiyetler arası sağkalım oranları, kadın ve erkeklerde sırasıyla 100.2 ve 45.7 ay ve bu istatistiksel olarak anlamlı saptandı ( $p=0.02)$. Yaş gruplarına göre sağkalım oranları, yașı 50 ve altı olanlar ile 50 yaşın üstündekiler sırasıyla 113.2 ve 65.1 ay ve gruplar arası istatistiksel olarak sağkalım farkı saptandı $(p=0.001)$. Hastaların tümörlerindeki progesteron reseptör(PR) durumuna göre, progesteron reseptör durumu negatif olanlarda sağkalım süresi 43.8 iken zayıf pozitif olanlarda 93.7 ay ve pozitif olanlarda 95.2 ay saptandı ( $p=$ 0.035). Östrojen reseptör(ER) durumu göre yapılan analizde, tüm hastaların sadece 10'nunda (\%13.5) ER pozitif saptandı ve pozitif hastaların hepsi kadın cinsiyetinde olup erkek hastaların hepsinde ER negatif saptandı, aralarında istatistiksel anlamlı fark saptanmadı. Primer intrakraniyal tümörlerin en sık görülen tümörü meningiomaların kadın cinsiyette belirgin bir şekilde daha sık görülmeleri cinsiyet hormonlarını bu tümör gelişiminde belirgin etkisini düşündürmekte. Bu çalışma ile yaş ve cinsiyet ile beraber progesteron reseptör durumunun prognostik faktör olduğunu belirledik.

Anahtar Kelimeler: Meningiom, Östrojen reseptörü, Progesteron reseptörü, Grade, Neoplazm 


\section{INTRODUCTION}

Meningioma is the most frequently reported primary brain tumor in adults, accounting for up to $20 \%$ of all intracranial neoplasms. ${ }^{1}$ Despite the fact that most are benign, there is great heterogeneity in the histology, recurrence rates, and survival outcomes of meningioma. The incidence in females is more than twice as high as in males ${ }^{2,3}$, and incidence increases with age. Clinical findings have long suggested the possibility of a hormonal influence in meningioma, and the higher incidence in females suggests that estrogen and progesterone may have roles in meningioma growth. An increase in size and/or symptoms of meningioma in the second and third trimesters of pregnancy has been reported; this is resolved after delivery. ${ }^{4,5}$ The effects of estrogen and progesterone on meningioma have been under investigation for more than three decades ${ }^{5}$, and several studies have shown the presence of receptors for progesterone (PR) and estrogen (ER) in tumors. ${ }^{6-9}$ However, the results from most case series have been inconsistent. A number of studies evaluating the prognostic value of PR and ER expression in meningiomas have found a lack of PR expression to be correlated with high tumor grade, high cellular proliferative index (Ki67 index), and tumor recurrence, although similar correlations have not been found by others. ${ }^{10-15}$

As it has been reported previously, higher incidence of meningiomas in females suggests that estrogen and progesterone hormones may have roles in the disease growth. In this study, we present a series of 74 meningiomas assayed for both ER and PR status using specific monoclonal antibodies with their clinical characteristics to figure out the relation between sex hormone receptors and prognosis of meningiomas, a long-term follow-up data from a single center.

\section{MATERIALS AND METHODS}

\section{Patient Population and Eligibility}

Patients receiving surgery for intracranial meningioma at the Department of Neurosurgery of Gazi Yasargil Training and Education Hospital between January 2007 and June 2018 were enrolled in this study. Data were retrospectively reviewed for 74 cases. The patients with pathologic diagnosis of meningioma $\geq 18$ year old were eligible, however, patients with all other pathologic diagnosis of intracranial tumor other than meningioma excluded. All surgical specimens were analyzed, checked, and confirmed by an experienced pathologist according to the World Health Organization (WHO) Classification of Tumors of the Central Nervous System, ranking them as WHO Grades I, II or III. The study was approved by the ethics committee of the hospital. The study followed ethical guidelines for trials that described in the Declaration of Helsinki.

\section{Histopathology}

Tumor specimens were fixed in $4.5 \%$ formalin solution for $24 \mathrm{~h}$, and embedded in paraffin blocks. Tissue sections measuring $4 \mathrm{~mm}$ in thickness were used for staining. Hematoxylin and eosin staining was performed for histological diagnosis. Histological subtype and grade were classified according to the WHO classification scheme by a single pathologist. Mitotic index was determined by counting the percent of cells with mitotic figures found in 10 high-power fields.

\section{Tumor Location Analysis}

Initial imaging was performed with contrast-enhanced magnetic resonance imaging (MRI). Data regarding the location of the tumor and characteristics of contrast enhancement were obtained from those images. Tumor locations were noted, and contrast-enhanced MRI scans were compared to pathological samples used for diagnosis after surgery, to determine consistency between the two different modalities. Post-treatment MRI examination was performed at 3 months after surgery, and every 3-6 months thereafter. Recurrence was diagnosed as regrowth detected by follow-up MRI.

\section{Immunohistochemical Analysis}

Immunohistochemical assays for the assessment of PR, ER, and Ki-67 were performed following the manufacturer's instructions for primary monoclonal rabbit antibodies against human PR (PR 1E2), 


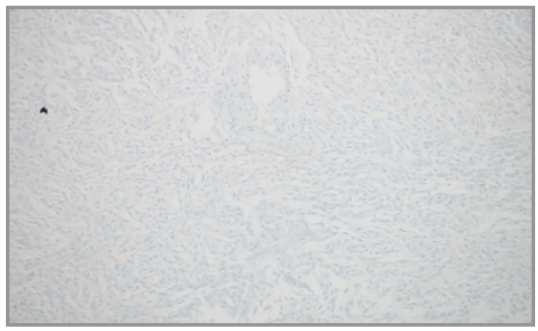

Figure 1. PR negative tumor tissue with no nuclear staining

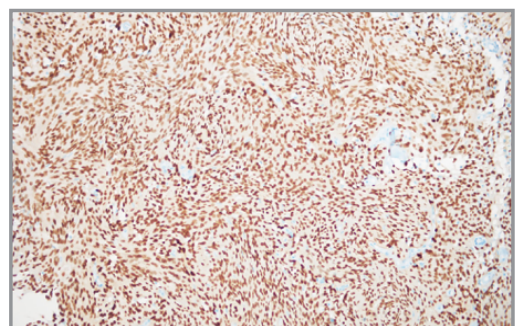

Figure 2. PR positive tumor tissue with $>10 \%$ nuclear staining.

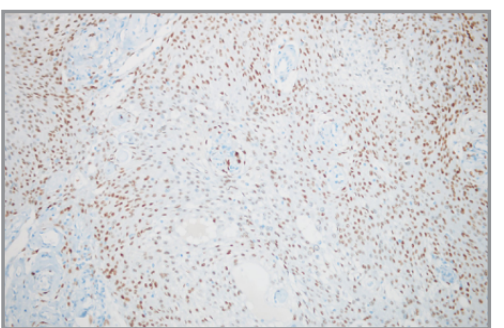

Figure 3. PR weakly positive tumor tissue with $1-9 \%$ nuclear staining.
ER (ER SP1), and Ki-67 (30-9), obtained from Ventana (Tucson, AZ, USA). Strong nuclear staining was accepted as positive for $\mathrm{Ki}-67$, and the percentage of positive tumor cell nuclei stained was recorded; tumors with no nuclear staining were scored as negative (Figure 1). In ER and PR evaluation, tumors were divided into three groups. Tumors were considered ER or PR positive if $>10 \%$ of tumor cell nuclei showed staining (Figure 2), or weakly positive if 1-9\% of nuclei were stained (Figure 3). Both were considered receptor-positive groups; tumor tissues that did not show any staining were scored as negative. A breast cancer specimen was used as a positive control for PR and ER immunostaining.

\section{Statistical Analysis}

Clinical data with continuous variables were summarized with descriptive statistics. Correlations between tumor grade and expression of PR, ER, and Ki67 were assessed. Correlations among PR expression, ER expression, and Ki67 index were also separately analyzed by linear regression in all meningioma groups. Continuous variables were compared between independent samples using Student's t-test or Mann-Whitney U-tests; chi-squared tests were used for comparisons between groups. Overall survival (OS) was defined as the time from initial surgery to death or to final follow up. Survival curves were generated using the KaplanMeier method, and the Cox proportional hazards test was used to analyze prognostic factors. Statistical analyses were performed using Statistical Package for the Social Sciences (SPSS) version 20.0. A P-value $<0.05$ was considered statistically significant.

\section{RESULTS}

A total of 74 patients were enrolled in our series; patient demographic characteristics and tumor locations are shown in Table 1. The distribution of PR positive patients by gender was given in Table 2 . There is no statistically significant difference in the distribution of these patients according to gender. Of the 74 patients, 58 were female $(78.4 \%)$ and 16 were male $(21.6 \%)$. The mean age of all patients at diagnosis was $53 \pm 13.6$ years; $54.02 \pm 13.2$ years for females and $49.5 \pm 14.7$ years for males. Patient overall survival (OS) was 91.4 months, and differed significantly by gender. Female and male OS times were 100.2 and 45.7 months, respectively $(\mathrm{P}=0.02$, Graphic 1 and 2). When patients were divided into two groups by age, there was a significant difference in OS between those aged 50 years and younger (Group A) and those older than 50 years (Group B), 113.2 and 65.1 months, respectively $(p=0.001$, Graphic 3$)$. Survival analysis by tumor tissue PR status identified another statistically significant difference in OS: in patients with PRnegative tumors it was 43.8 months, in those with weakly PR-positive tumors it was 93.7 months, and it was 95.2 months in those with strongly positive tumors ( $\mathrm{p}=0.035$, Graphic 4$)$. The most frequent site of tumor involvement was the frontal lobe (44.6\%). A total of 10 patients $(13.5 \%)$ had detectable ER expression by immunohistochemistry. All the tumor tissue samples positive for ER were from female patients, and all tumor tissue samples from males were negative for ER staining. Significant levels of PR expression were detected in tumors from 67 patients $(90.4 \%)$. Of the 57 tumors from females, 51 were positive for PR, and 15 of 16 tumors from males were positive. There was a statistically significant negative correlation 


\begin{tabular}{|c|c|}
\hline Overall patients & $74(100 \%)$ \\
\hline Female & 58 (78.4\%) \\
\hline Male & $16(21.6 \%)$ \\
\hline \multicolumn{2}{|l|}{ The mean age in years } \\
\hline Overall & $53 \pm 13.6$ \\
\hline Female & $54.02 \pm 13.2$ \\
\hline Male & $49.5 \pm 14.7$ \\
\hline \multicolumn{2}{|l|}{ Location } \\
\hline Frontal & $33(44.6 \%)$ \\
\hline Parietal & $10(13.5 \%)$ \\
\hline Temporal & $15(20.3 \%)$ \\
\hline Occipital & $10(13.5 \%)$ \\
\hline Cerebellar & $2(2.7 \%)$ \\
\hline Interhemisferic & $2(2.7 \%)$ \\
\hline Vertebral & $2(2.7 \%)$ \\
\hline \multicolumn{2}{|l|}{ Histological grade, no. of cases } \\
\hline Grade I & $64(86.5 \%)$ \\
\hline Grade ॥ & $9(12.2 \%)$ \\
\hline Grade III & $1(1.3 \%)$ \\
\hline \multicolumn{2}{|l|}{ ER expression, no. of cases } \\
\hline Negative & $64(86.5 \%)$ \\
\hline Weak positive & 7 (9.5\%) \\
\hline Positive & $3(4 \%)$ \\
\hline \multicolumn{2}{|l|}{ PR expression, no. of cases } \\
\hline Negative & 7 (9.5\%) \\
\hline Weak positive & $13(17.5 \%)$ \\
\hline Positive & $54(73 \%)$ \\
\hline \multicolumn{2}{|l|}{ The mean Ki67(\%), no. of cases } \\
\hline$(+)$ & 57 (77\%) \\
\hline$(++)$ & $12(16.2 \%)$ \\
\hline$(+++)$ & $5(6.8 \%)$ \\
\hline \multicolumn{2}{|l|}{ Recurrence } \\
\hline Yes & $4(5.4 \%)$ \\
\hline No & $70(94.6 \%)$ \\
\hline \multicolumn{2}{|l|}{ Outcome at last follow-up } \\
\hline Dead & $24(32.4 \%)$ \\
\hline Alive & $50(67.6 \%)$ \\
\hline \multicolumn{2}{|l|}{ The mean size of tumor, $\mathrm{cm}$} \\
\hline Overall & $4.1 \pm 2.2$ \\
\hline Female & $4.0 \pm 2.3$ \\
\hline Male & $4.6 \pm 1.8$ \\
\hline \multicolumn{2}{|l|}{ OS } \\
\hline Overall OS & 91.4 months \\
\hline Overall 5 years survival rate, \% & $69 \%$ \\
\hline Female OS & 100.2 months \\
\hline Female 5 year survival rate, \% & $77 \%$ \\
\hline Male OS & 45.7 months \\
\hline Male 5 years survival rate, \% & $25 \%$ \\
\hline
\end{tabular}

between PR staining intensity and tumor grade $(p<0.022)$. There was no correlation between ER and PR status $(\mathrm{p}=0.329), \mathrm{ER}$ and tumor grade $(\mathrm{p}=$ 0.057), or ER and Ki67 index ( $p=0.110)$. There was no statistically significant gender difference in tumor size; mean tumor sizes were $4 \mathrm{~cm}$ and 4.68 $\mathrm{cm}$ for females and males, respectively $(\mathrm{p}=0.288)$. There was no statistically significant relationship between tumor grade and ER staining intensity of tumor cells; $89.1 \%$ of Grade I tumors were negative and $10.9 \%$ of them were positive, $66.7 \%$ of Grade II tumors were negative and $33.3 \%$ of them were positive, and $100 \%$ of Grade III tumors were positive $\left(X^{2}=8.948 ; \mathrm{p}=0.062\right)$. There was a statistically significant relationship between tumor grade and PR staining intensity; $7.8 \%$ of Grade I tumors were negative and $81.2 \%$ were positive, $11.1 \%$ of Grade II tumors were negative and $88.9 \%$ were positive, and $100 \%$ of Grade III tumors were negative $\left(X^{2}=11.6 ; p=0.02\right)$. The majority of male and female patients had Grade I tumors, whereas the remaining small proportion of the patients had Grade II or III tumors ( $\left.X^{2}=7.1 ; \mathrm{p}=0.028\right)$.

\section{DISCUSSION}

Several studies have confirmed a female predominance in the occurrence of meningiomas, with incidence rates 1.5 to 2 -fold higher in females than in males. ${ }^{2,3}$ In our case series, this female predominance was particularly notable, with an almost 4-fold higher incidence seen in females.

The female predominance in meningioma incidence has suggested that the growth of meningiomas may be hormone dependent. The potential of sex hormones to influence the emergence and growth of meningiomas has been examined in several studies, which have demonstrated the presence of PR and ER in these tumors. ${ }^{6,16} \mathrm{PR}$ status has been correlated with tumor grade, being more frequently reported in Grade I than in other grades of atypical/ malignant meningiomas. ${ }^{12,15,17}$ Sex hormones have been proven to have growth effects in breast cancer, and it is possible that meningioma growth is similarly regulated. ${ }^{18,19}$ Sex hormones activate their receptors in tissues, upregulating the transcription of target genes and promoting cell cycle progression, leading to the accumulation of large numbers 
International Journal of Hematology and Oncology

Table 2. Gender distrubitions of the progestron posivite patients ( $\mathrm{n} \%$ )

\begin{tabular}{|lllll|}
\hline Gender & Negative & Weak positive & Positive & p \\
\hline Female $(n=58)$ & $6(8.1 \%)$ & $10(13.5 \%)$ & $42(56.8 \%)$ & 0.882 \\
Male $(n=16)$ & $1(1.4 \%)$ & $3(4.1 \%)$ & $12(16.2 \%)$ & \\
Total & $7(9.5 \%)$ & $13(17.6 \%)$ & $5473.0 \%)$ & \\
\hline
\end{tabular}

of proliferating cells in $\mathrm{G} 2$ and $\mathrm{M}$ phases of the cell cycle. ${ }^{20-22}$ In our study, Grade I meningioma tissues had higher PR expression, consistent with previous reports. PR expression was less frequent in Grade II and III tumors. In our series, ER expression and tumor grade were not significantly correlated, likely due to the small sample size.

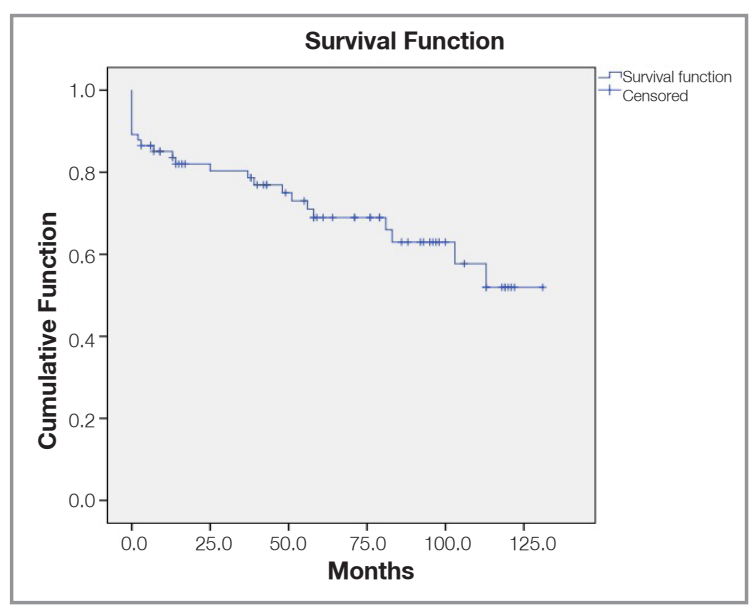

Graphic 1. Kaplan-Meier survival curve, OS of patients by all histological and gender subtypes

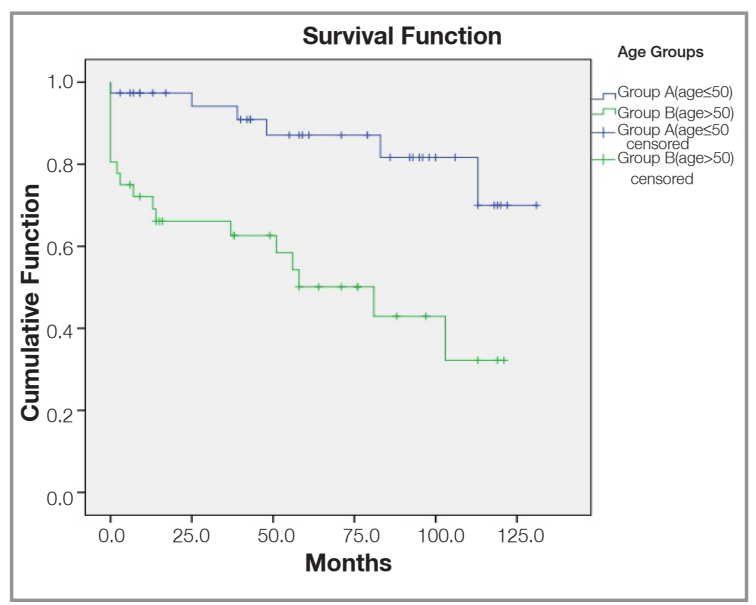

Graphic 3. Kaplan-Meier survival curve, OS of patients by age groups which are group A (age younger or equal 50 years old), and group B (age older than 50 years old).
The common distribution of meningiomas according to grade has been reported in a number of published case series, in which Grade I meningiomas constituted around $90 \%$, Grade II around $7 \%$, and Grade III around 2\%..$^{23-26}$ Our series was consistent with the literature, although the numbers of patients with Grade II and Grade III men-

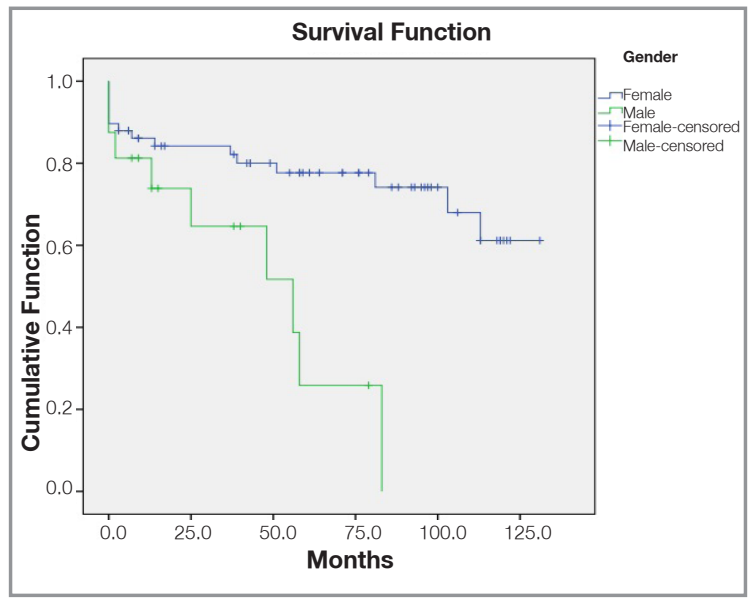

Graphic 2. Kaplan-Meier survival curve, OS of patients by females and male and gender subtypes

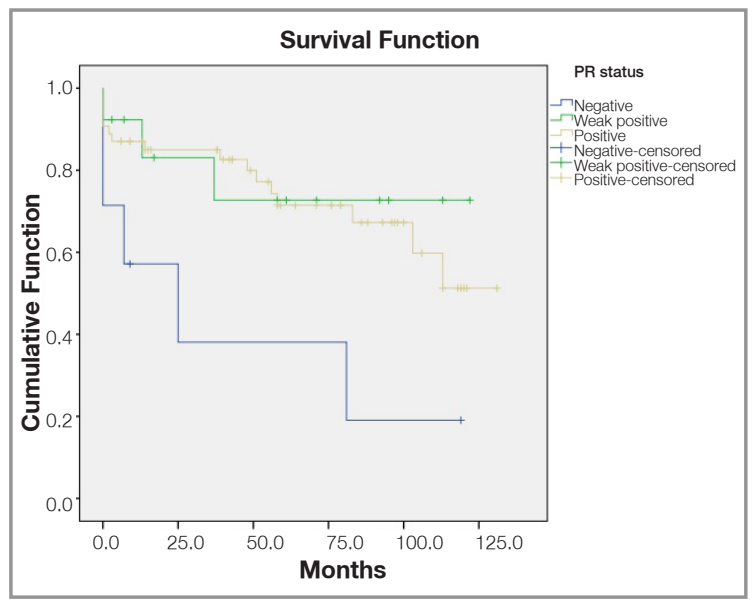

Graphic 4. Kaplan-Meier survival curve, OS of patients according to progesteron receptor status that include three subgroup as negative, weak positive, and positive.

UHOD Number: 1 Volume: 29 Year: 2019 
ingiomas were limited. Grading systems based on histopathological features have some limitations in predicting the biological behavior of meningiomas, and should be combined with other factors such as surgery, age, gender, location, ER, PR, and Ki67 status, and degree of brain invasion. ${ }^{27} \mathrm{Ki67}$ status correlates with histological grade, and high mitotic index (reflected by Ki67) has generally been considered a strong indicator of tumor recurrence. ${ }^{28}$ This allows Ki67 status to be used as an ancillary factor in grading meningiomas. ${ }^{29}$ The correlation between tumor grade and Ki67 index was not statistically significant in our study.

The mechanism underlying the inverse relationship between PR expression and tumor progression remains unclear; there is thought to be a higher rate of mitosis and increased angiogenesis in tumor cells with low PR expression. ${ }^{10}$ In our study, the mean tumor sizes in PR status subgroups were quite different; PR-negative tumors were larger than PR-positive tumors, which may reflect the relationship between sex hormones and tumor aggressiveness. Several studies have investigated the roles of ER and PR in meningioma to determine their value as prognostic markers for predicting tumor behavior. ${ }^{17}$ It has generally been noted that meningiomas commonly express PR, but that ER expression is less common in these tumors. ${ }^{15,30}$ Our study found that patients with negative PR status had shorter survival times than patients with weakly positive or positive PR status, suggesting that PR status may be a useful prognostic factor for meningiomas.

In our study, the majority of patients were females with Grade I tumors, and the overall survival rate differed significantly between females and males, with 5-year survival rates of $77 \%$ for females and $25 \%$ for males. This was also consistent with earlier studies. ${ }^{31}$ Due to their rapid growth and potential for brain invasion, Grade III meningiomas have reported 5-year survival rates of around $44 \%$. This grade has been found more frequently in males, and has been seen to emerge at much younger ages. ${ }^{32-34}$ In our study, the patients were diagnosed at older ages, and had much better survival rates; the most likely explanation is that the majority of our patients were females with Grade I tumors.
Meningiomas are generally diagnosed between the ages of 35 and 55 years, and are rarely seen before puberty or after 74 years of age. Some authors have reported that the average age of meningioma patients at diagnosis is approximately 55 years, and that age $<60$ years may be a useful prognostic factor. ${ }^{35}$ In our survival analysis, patients aged 50 years or younger had significantly better survival rates than did those older than 50 years of age. An analysis of over 9,000 patients with meningioma based on the National Cancer Database determined that age at diagnosis, especially for patients over 65 years of age, was a negative prognostic factor. ${ }^{36}$ Concordantly, in our study, older age at diagnosis showed a highly significant relationship with shorter survival time.

The frontal lobe was the most common tumor site noted in our study; tumor location was not found to have a significant effect on tumor incidence. Similarly, Mansouri et al. reported that meningiomas at all locations demonstrated a similar recurrence rate. That study found that the extent of resection was a key predictor of recurrence. ${ }^{37}$

Limitations: Our study was planned retrospectively and covers a period of 11 years. Currently molocular studies and markers are more common than the hormone reseptor status, these situations constitute one of the limitations of our study. Therefore, we suggest to plan molecular-based, prospective, randomized, controlled, anda doubleblind studies in the future. Another major limitation of our study was its small sample size. This and other limitations were associated with the fact that it was a retrospective study at a single institution in Turkey. Therefore, the number of cases was limited and the patient distribution was not balanced between genders. The comparisons between groups may have been influenced by possible effects of the distribution of the limited number of patients enrolled. A lack of standardized methods for immunostaining, due to the heterogeneity of some tumor regions and resected tumor tissues, and other issues with assessing staining patterns, are possible causes of variability in the results. 


\section{CONCLUSIONS}

As has been reported many times in previous studies, the female predominance in meningiomas strongly suggests a role for sex hormones in their growth. Consistent with this hypothesis, we found PR status to be a prognostic factor in our meningioma case series. A better understanding of this association may be gained by enlarging the sample of meningioma patients whose tumor PR status has been established. We also found age and gender to be prognostic factors, as has been reported previously. One major limitation of our study was the small sample size. According to the results of this and previous studies, meningioma patients over 50 years, male patients, and those with negative PR status are at increased risk of death. Large cohorts of patients will be needed to further evaluate these prognostic factors and their effects on survival.

\section{REFERENCES}

1. Schellinger KA, Propp JM, Villano JL, McCarthy BJ. Descriptive epidemiology of primary spinal cord tumors. J Neurooncol 87: 173-179, 2008.

2. Christensen HC, Kosteljanetz M, Johansen C. Incidences of gliomas and meningiomas in Denmark, 1943 to 1997. Neurosurgery 52: 1327-1333, 2003.

3. Nakasu S, Hirano A, Shimura T, Llena JF. Incidental meningiomas in autopsy study. Surg Neurol 27: 319-322, 1987.

4. Bickerstaff ER, Small JM, Guest IA. The relapsing course of certain meningiomas in relation to pregnancy and menstruation. J Neurol Neurosurg Psychiatry 21: 89-91, 1958.

5. Roelvink NC, Kamphorst W, van Alphen HA, Rao BR. Pregnancy-related primary brain and spinal tumors. Arch Neurol 44: 209-215, 1987.

6. Blankenstein MA, Blaauw G, Lamberts SW. Progestin and estrogen receptors in human meningioma. Clin Neuropharmacol 7: 363-367, 1984.

7. Khalid H. Immunohistochemical study of estrogen receptorrelated antigen, progesterone and estrogen receptors in human intracranial meningiomas. Cancer 74: 679-685, 1994.

8. Schrell UM, Adams EF, Fahlbusch R, et al. Hormonal dependency of cerebral meningiomas. Part 1: Female sex steroid receptors and their significance as specific markers for adjuvant medical therapy. J Neurosurg 73: 743-749, 1990.

9. Maxwell M, Galanopoulos T, Neville-Golden J, Antoniades $H N$. Expression of androgen and progesterone receptors in primary human meningiomas. J Neurosurg 78: 456-462, 1993.
10. Fewings PE, Battersby RD, Timperley WR. Long-term follow up of progesterone receptor status in benign meningioma: a prognostic indicator of recurrence? J Neurosurg 92: 401405, 2000.

11. Carroll RS, Zhang J, Dashner K, Black PM. Progesterone and glucocorticoid receptor activation in meningiomas. Neurosurgery 37: 92-97, 1995.

12. Hsu DW, Efird JT, Hedley-Whyte ET. Progesterone and estrogen receptors in meningiomas: prognostic considerations. J Neurosurg 86: 113-120, 1997.

13. Bouillot P, Pellissier JF, Devictor B, et al. Quantitative imaging of estrogen and progesterone receptors, estrogen-regulated protein, and growth fraction: immunocytochemical assays in 52 meningiomas. Correlation with clinical and morphological data. J Neurosurg 81: 765-773, 1994.

14. Wolfsberger S, Doostkam S, Boecher-Schwarz HG. Progesterone-receptor index in meningiomas: correlation with clinico-pathological parameters and review of the literature. Neurosurg Rev 27: 238-245, 2004.

15. Brandis A, Mirzai S, Tatagiba M. Immunohistochemical detection of female sex hormone receptors in meningiomas: correlation with clinical and histological features. Neurosurgery 33: 212-217,1993.

16. Bozzetti C, Camisa R, Nizzoli R. Estrogen and progesterone receptors in human meningiomas: biochemical and immunocytochemical evaluation. Surg Neurol 43: 230-233,1995.

17. Roser F, Nakamura M, Bellinzona M. The prognostic value of progesterone receptor status in meningiomas. J Clin Pathol 57: 1033-1037, 2004.

18. Pike MC, Spicer DV, Dahmoush L, Press MF. Estrogens, progestogens, normal breast cell proliferation, and breast cancer risk. Epidemiol Rev 15: 17-35, 1993.

19. Key T, Appleby P, Barnes I, Reeves G. Endogenous sex hormones and breast cancer in postmenopausal women: reanalysis of nine prospective studies. J Natl Cancer Inst 94: 606-616, 2002.

20. Tian JM, Ran B, Zhang CL, et al. Estrogen and progesterone promote breast cancer cell proliferation by inducing cyclin G1 expression. Braz J Med Biol Res 51: 1-7, 2018.

21. Kawazu M1, Saso K, Tong Kl, et al. Histone demethylase JMJD2B functions as a co-factor of estrogen receptor in breast cancer proliferation and mammary gland development. PLoS One 6: e17830, 2011.

22. Jiang CF, Li DM, Shi ZM, et al. Estrogen regulates miRNA expression: implication of estrogen receptor and miR-124/ AKT2 in tumor growth and angiogenesis. Oncotarget 7: 36940-36955, 2016.

23. Perry A, Scheithauer BW, Stafford SL, et al. "Malignancy" in meningiomas: a clinicopathologic study of 116 patients, with grading implications. Cancer 85: 2046-2056, 1999. 
24. Kasuya $\mathrm{H}$, Kubo O, Tanaka M, et al. Clinical and radiological features related to the growth potential of meningioma. Neurosurg Rev 29: 293-296, 2006.

25. Perry A, Stafford SL, Scheithauer BW, et al. Meningioma grading: an analysis of histologic parameters. Am J Surg Pathol 21: 1455-1465, 1997.

26. Babu S, Uppin SG, Uppin MS, et al. Meningiomas: correlation of Ki67 with histological grade. Neurol India 59: 204-207, 2011.

27. Nakasu S, Nakasu Y, Nakajima M, et al. Preoperative identification of meningiomas that are highly likely to recur. J Neurosurg 90: 455-462, 1999.

28. Louis DN, Ohgaki H, Wiestler OD, et al. The 2007 WHO Classification of Tumours of the Central Nervous System. Acta Neuropathol 114: 97-109, 2007.

29. Louis DN, Ohgaki H, Wiestler OD, et al. The 2007 WHO classification of tumours of the central nervous system. Acta Neuropathol 114: 97-109, 2007.

30. Viac J, Schmitt D, Claudy A, et al. Immunological and immunocytochemical studies of the inflammatory infiltrating cells of cutaneous tumors. Ann Immunol (Paris) 128: 109-110, 1977.

31. Zhang GJ, Zhang GB, Zhang YS, et al. World Health Organization Grade III (Nonanaplastic) Meningioma: Experience in a Series of 23 Cases. World Neurosurg 112: e754-e762, 2018.

32. Dziuk TW, Woo S, Butler EB, et al. Malignant meningioma: an indication for initial aggressive surgery and adjuvant radiotherapy. J Neurooncol 37: 177-188, 1998.

33. Hug EB, Devries A, Thornton AF, et al. Management of atypical and malignant meningiomas: role of high-dose, 3D-conformal radiation therapy. J Neurooncol 48: 151-160, 2000.
34. Pasquier D, Bijmolt S, Veninga T, et al. Atypical and malignant meningioma: outcome and prognostic factors in 119 irradiated patients. A multicenter, retrospective study of the Rare Cancer Network. Int J Radiat Oncol Biol Phys 71: 1388-1393, 2008.

35. Kim YJ, Ketter R, Henn W, et al. Histopathologic indicators of recurrence in meningiomas: correlation with clinical and genetic parameters. Virchows Arch 449: 529-538, 2006.

36. McCarthy BJ, Davis FG, Freels S, et al. Factors associated with survival in patients with meningioma. $\mathrm{J}$ Neurosurg 88: 831-839,1998.

37. Mansouri A, Klironomos G, Taslimi S, et al. Surgically resected skull base meningiomas demonstrate a divergent postoperative recurrence pattern compared with non-skull base meningiomas. J Neurosurg 125: 431-440, 2016.

\section{Correspondence}

Dr. Abdurrahman ÇETIN

Talaytepe Mahallesi

Elazig Yolu Üzeri 10. Km

21010, Kayapinar

DIYARBAKIR / TURKEY

Tel: (+90-507) 5636414

e-mail: acetin2147@gmail.com 